\title{
Interfaith Dialogue and Theological Schools
}

\author{
by Stephen Downs
}

A $s$ a Christian theologian, the context of my remarks today is the notion, usually attributed to Pope Paul VI, that dialogue (including interfaith dialogue) is a new way of being the Church, a new way of being Christian. As often happens with developments in the Church, this idea both reflects and promotes thinking found in the world beyond the Church. I do think this idea - that people today need to engage in dialogue - has grown in the last fifty years or so, even if it is not embraced by everyone. The focus of my remarks will be how this principle informs the contemporary, tertiary theological school. My experience is limited to Christian schools. I imagine there will be both similarities and differences with other faith-based colleges.

To help me do this, I will refer to three roles that the theological college performs: teaching theology and ministry; general education; and community engagement. In practice these roles frequently overlap; and that is true

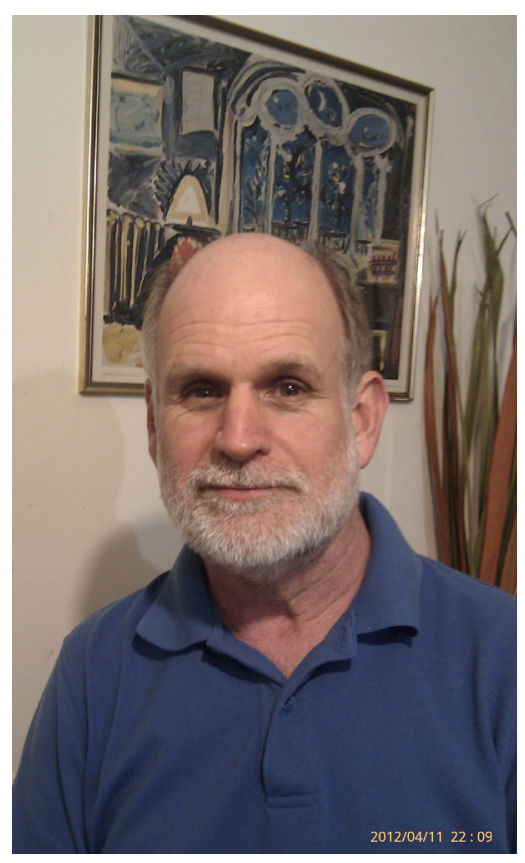
with respect to interreligious dialogue. But making these distinctions can help us identify some of the different ways theological schools relate to dialogue.

\section{Teaching Theology and Ministry}

This is usually thought of as the 'core business' of theological schools.

Among the most advanced connections with interfaith dialogue are those found in biblical studies and biblical theology. So, for example, every major mainstream work on New Testament Theology or on Christology (on the 'historical Jesus' for example) includes references to Jewish scholarship and perspectives. Undergraduates are routinely exposed to questions about the relationship between Jesus, the Christian scriptures and the church - to Judaism. They will be familiar with work by such scholars as Geza Vermes. If they are fortunate they will have opportunities to hear Jewish scholars.

Turning to Systematic Theology, there has been an impact on such fundamental theological notions as God, humanity, revelation, grace and salvation. Our heightened awareness and experience of other faiths raise questions about the universality and particularity of each of these major Christian doctrines. These are now noted and sometimes investigated in theology classes and certainly in theological research. So, for example, what is the scope of the salvation that Christians believe is effected by the death and resurrection of Jesus? Or what status should 


\section{"Disciplinary areas} that are valued, because of their usefulness for theological study, include philosophy, literature and the arts, sociology, media and popular culture, and a knowledge of other faiths."
Christians give to the sacred texts or 'scriptures' of other faiths? The special connection between Christianity and Judaism has been noted. Some theologians are starting to ask whether there is also a special relationship of some sort between Christianity and Islam.

We should also note that interreligious dialogue has become a distinct subject/topic in Christian theology, to which many undergraduates will have some exposure. And in theological schools around the world there are research centres dedicated to it (e.g., the Centre for Christianity and Interreligious Dialogue at Heythrop College, University of London - where I have just spent three months). Most of these include the dedicated study of particular faiths (e.g., Australian Catholic University's Centre for Interreligious Dialogue includes a chair in Islamic studies and Muslim-Catholic relations).

In the field of Ministry Studies, which is offered by some theological schools, interfaith relations may be included in the teaching of future ministers. This is probably less true, however, than ecumenical or inter-church relations. There is a growing recognition of the need for cooperation between different church communities and different faith communities. I think the increasing influence of secularism in Australian society contributes to this. But I suspect that interfaith dialogue does not feature as much in this field of theological education as in some others, such as biblical studies. This is or would be a shame because I know from my own teaching experience that interfaith dialogue can greatly assist with what is now commonly termed transformative learning; that is to say, learning at the deepest level, that may include an experience of disorientation, but that leads to a more inclusive and integrative way of being.

\section{General Education}

In addition to theology and ministry studies, theological schools also provide studies in a range of other disciplines. Sponsoring churches often encourage ministry candidates to have another degree or major. Disciplinary areas that are valued, because of their usefulness for theological study, include philosophy, literature and the arts, sociology, media and popular culture, and a knowledge of other faiths. The fact that the role of religion in Australian society is now frequently and sometimes hotly debated in the public sphere has, I am sure, contributed to this. And where Judaism occupies a special place in Christian theology, a knowledge of Islam is probably valued most in terms of understanding religion and society. It seems to me that theological schools in Australia also value a knowledge of Aboriginal religions and spirituality, secular humanism, and 'youth spirituality'. I am unsure if knowledge of other religious traditions, including some that are increasingly evident in Australian society, is valued. Nor am I sure a knowledge of modern Judaism, as distinct from the Judaism of the first century or earlier, is properly recognised. Sometimes these sorts of studies are incorporated with 


\section{"For all these}

reasons, there

are grounds to

expect and to hope

that the role of

interfaith dialogue

in theological schools

will continue to

grow." the theology curriculum broadly conceived. They can include an experiential component (such as afternoon tea with members of the local Muslim student association), and some treatment of interfaith relations or dialogue.

\section{Community Engagement}

Finally we should note that theological schools, including those in public universities, also identify community engagement as a major aspect of their operation. Consequently they encourage their faculty and students to contribute to community activities, including that of interfaith relations and dialogue. So, for example, Flinders University theology faculty and students are members of the Multifaith Association, the Council of Christian and Jews, and church networks and commissions for ecumenical and interfaith relations. Theological schools also host community events that promote interfaith dialogue. In a few weeks time, for example, the Flinders Unversity/Adelaide Theological Centre Annual Lecture in Theology will be given by an American Jewish scholar, Professor Amy-Jill Levine, who teaches in a Christian theological school. It is often in this context that they conduct or organise visits to diverse places of worship.

\section{Conclusion}

It might seem from what I have said that interfaith dialogue features prominently and broadly in theological schools. Regrettably it would be an exaggeration to claim that. What I do believe is that the situation has developed considerably since the 1960s and 70s. And that there are a number of different places in the life and work of theological schools today where interfaith dialogue may be found. The extent, the forms and the character of this presence depend a great deal on each institution and its purposes and on the interests and expertise of its faculty. I have also indicated that as well as religious, theological and scholarly reasons why interfaith relations can play a significant part in theological schools, there are also social and even socio-political factors at play. For all these reasons, there are grounds to expect and to hope that the role of interfaith dialogue in theological schools will continue to grow. 